\title{
Evaluation of Physical, Mechanical and Chemical Properties of Cedar and Sycamore Woods after Heat Treatment
}

\author{
Eman Nabil ${ }^{1}$, Naglaa Mahmoud ${ }^{2}$, Ahmed Youssef ${ }^{3}$, Essam Saber ${ }^{4}$, Samir Kamel $^{4}$ \\ ${ }^{1}$ Cheops Museum, Egypt. \\ ${ }^{2}$ Conservation Department, Faculty of Archeology, Fayoum University, Egypt. \\ ${ }^{3}$ Packaging Materials Department, National Research Centre, El Behooth St., Dokki, \\ Giza, Egypt. \\ ${ }^{4}$ Cellulose and Paper Department, National Research Centre, El Behooth St., Dokki, \\ Giza, Egypt.
}

\begin{abstract}
7 HIS WORK is concerned with the study of the impact of heat (160, 180, 200 and $220^{\circ} \mathrm{C}$ ), in addition to the time of exposure on cedar and sycamore woods for different times (2, 4 and 6 hours). The change in the color of the wood was studied. The mechanical properties, rate of mass loss, and decreases on the density of the heat treated woods were evaluated. The surface roughness and the fiber separation were also studied using scanning electron microscopy (SEM). The obtained results showed that, both types of wood were affected by heat treatment $\left(160\right.$ and $\left.180^{\circ} \mathrm{C}\right)$, where the surface smoothness increased for both also it was detected as temperatures rose to $\left(200-220^{\circ} \mathrm{C}\right)$, there is a high roughness in the outer surface of the wood with increased separation of fibers. The anatomical structure of the wood was examined via (SEM), where the cedar samples showed higher quality in heat resistance than sycamore. The heat treated wood was investigated using FT-IR spectroscopy to study the changes in the wood spectra structure, as well as X-ray diffraction pattern (XRD) analysis were also used to study the extent of change in the crystallization of cellulosic wood.
\end{abstract}

Keywords: Cedar, Sycamore, Heat treatment, TGA, FTIR, SEM, XRD.

\section{Introduction}

Throughout history, wood has been one of the most important renewable natural components, possessing unique physical and chemical properties, making it one of the most widely used materials in all works of art [1]. Wood as cellulosic material is exposed, as other materials, for many damage factors, such as influencing the deterioration of wood material, is high temperature $[2,3]$. The heat impacts on all components of wood, and develops severe changes in the basic components of the wood, from the declination of the proportion of cellulose, lignin and hemicellulose, which is reflected in the weakness of mechanical properties and the occurrence of physical changes through a complex damage mechanism, and the study of such mechanism of these changes is important to preserve the wooden antique pieces [4]. Wood has been used for the production of various artifacts, since the dawn of history due to its enormous properties (strength, durability, elasticity information, etc.) [5], which are part of the cultural heritage [6]. However, being a biological material, the cellulosic materials of wood suffers from the same fate of natural materials in terms of exposure to many damage factors $[7,8]$.

The most dangerous factors wood monuments are exposed to high temperatures [9] which lead to the phenomenon of thermal degradation of wood [10]. The research addresses the mechanism of thermal degradation of wood and many scientists have attempted to explain this phenomenon, including Florian [11], where he defined the thermal degradation as the temperature and time period in which wood is subjected to irreversible changes. Miyuki [12] also defined thermal degradation as the absorption by organic matter, including wood, of thermal energy, which leads to molecule agitation, consequently would affect

\footnotetext{
*Corresponding author e-mail: amyoussef27@yahoo.com 
the chemical components of the wood (cellulose, hemicellulose and Lignin). Hemicellulose is the most heat affected component, and it composed the bulk of the supporting plant cell structure, followed by cellulose, the main component of the cell wall [13].

The least affected component is the lignin, which is the most important component in wood tissue formation, as it gives stiffness to the cell prepared of $10 \times 1 \times 1 \mathrm{~cm}$ in dimensions for bending tests. And the preparation of samples of 2 $\times 2 \times 2 \mathrm{~cm}$ in dimensions for compression tests as in the physical and chemical tests were conducted on the same samples of the above dimensions.

All samples were weighed before and after heat treatment and by applying the law of mass reduction rate.

Sample mass after final limitation- Sample mass before final limitation

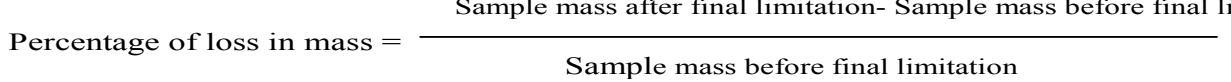

wall, and acts as the defense line against the microorganisms and prevents water leakage from the cell wall [15]. The thermal degradation of wood greatly weakens wood structure, and the wood becomes fragile, breakable and vulnerable to lose with decreasing in weight through complex damage mechanism. In addition to the color change of wood and the change in the outer texture of the wood surface [16]. As the temperature continues to rise, the stiffness of the wood decreases accompanied with changing in its dimensions which eventually leads to the occurrence of cracks and breakouts, while the wood itself becomes fragile and cannot be handled by hand, this damage is final and irreversible [17, 18]. The process of thermal degradation of wood is not done at a similar and constant rate in all types of wood [19].

Therefore this work is interested in studying the impact of thermal treatment of wood at different temperatures $\left(160,180,200\right.$ and $\left.220^{\circ} \mathrm{C}\right)$ for three time periods on the chemical, physical and mechanical properties in two types of wood. Two types of wood were selected; one of them is soft wood (Cedar), which is considered as a good type of wood, and resistant to fungal infection because of its content of high concentrations of chemicals (resins, waxes and oils) which represent a natural fungicide [20]. The sycamore wood has been selected as a hardwood, with its habitat in Egypt, where the ancient Egyptian had used it since the fifth dynasty, in the manufacture of coffins [21].

\section{Materials and Methods}

\section{Materials}

Cedar and Sycamore woods were delivered from Lebanon\& Egypt, respectively.

Experiments of thermal degradation of wood Samples of cedar and sycamore woods were
The percentage of loss in the mass has been calculated.

By calculating the mass and size of the samples before and after the heat treatment, and recording the results, the rate of loss in the density of both cedar and sycamore wood was calculated by applying the density law.

$$
\text { Density }=\frac{\text { Massin } \mathrm{Kg}}{\text { Volume in } \mathrm{M}^{3}}
$$

Heat treatment has taken place in LABTECHkiln oven at the National Research Center, Giza, Egypt

\section{Characterization}

\section{Mechanical properties}

The bending resistance and compressive resistance were measured when the samples were subjected to different temperatures and conducting a comparison between those samples and standard samples according to the ASTM D638-91 standard using a universal testing machine LK10k (Hants, UK) fitted with a $5 \mathrm{kN}$ load cell, and operated at a rate of $5 \mathrm{~mm} / \mathrm{min}$ on the samples that were cut to suit the operating conditions of the machine for both bending and compression tests. The unit of measurement is (Newton).

\section{The color measurements}

Ultra Scan PRO Hunter lab mead in U.S.A. was used to register the rate of color changes for both sycamore and cedar at the above mentioned temperatures.

\section{Morphological properties}

Scanning Electron Microscope for samples was examined using SEM Model Quanta 250 FEG (Field Emission Gun) attached with EDX 
Unit (Energy Dispersive X-ray Analyzes), with accelerating voltage $30 \mathrm{~K}$.V., magnification $14 \mathrm{x}$ up to 1000000 and resolution for Gun.1n).was used for the examination of the external surface of wood and anatomical structure of thermally treated wood

\section{Thermal processing}

The study dealt with heat processing of samples at different temperatures $(160,180,200$ and $\left.220^{\circ} \mathrm{C}\right)$ that for three time periods $(2,4$ and 6 hours) for each temperature.

\section{Results and Discussions}

\section{Visual examination}

By continuous heat treatment of the wood, severe physical changes have taken place in all samples, as the color of the wood gradually changed from yellowish brown to dark black with cross shrinkage of the samples and the appearance of capillary cracks at the beginning of the heat treatment, then developed into deep and wide cracks through the granules and spread all over the surface, reaching the occurrence of breaking and crashing in the samples. The samples became, at the end of the heat treatment, very weak and fragile. Tables 1 and 2 display the precise visual description of both types of woods after thermal treatment. Cedar wood differed from sycamore wood in terms of the degree of color change and the severity of the cracks and the increase in their number, where the Cedar wood has appeared more resistant than sycamore wood. The rapid collapse of sycamore wood was observed at the beginning of heat treatment.

\section{Color change}

The thermally treated wood is characterized by a significant change in color degree compared to standard samples. The degree of color change depends on temperature more than the period of heat exposure, as well as color change is associated with the type of wood [22, 23]. Color change is a reflection of the chemical changes that occur, where hemicellulose and cellulose are accountable for the degree of change in color of wood [12, 24 and 26]. The result of heat treatment was clearly visible to the naked eye as shown in Tables $1 \& 2$, showing the color change of sycamore and cedar woods after heat treatment. A significant change in $(\Delta \mathrm{E})$ registering the rate of color change for both sycamore and cedar woods (Fig. 1 \& 2). By comparing the results of color change for both woods, the color change was appearing high in case of cedar wood.

\section{Surface roughness}

The phenomenon of surface roughness is a complex phenomenon is due to several factors such as (anatomical structure of wood, the characteristics of growth, machines, treatments, vascular, cell cavity, width of secondary rings and hardness) [26]. Studies have shown that in good types of wood, surface roughness constantly decreases with temperatures rising [27] and as temperature increases, the surface roughness decreases; however, continuous heat rise is counterproductive [28]. The rate of change in the physical and mechanical properties of the wood begins at $150^{\circ} \mathrm{C}$, as the temperature rises higher than $150^{\circ} \mathrm{C}$, surface roughness increases [29].

The examination of the external surface shows that the type of wood played a large role in terms of temperature sensitivity, as in the sycamore wood, which is characterized with the roughness of the surface in the standard sample, the surface softness increased at the onset of the exposure to $180^{\circ} \mathrm{C}$, however, soon the surface showed more roughness as the temperature increased from 180 to $200^{\circ} \mathrm{C}$, with the increase in the rate of fiber shattering and the separation with the loss of large parts of the wood fiber, until the wood reached an advanced stage of damage and surface roughness at $200^{\circ} \mathrm{C}$. The outer surface of the standard sample of cedar wood was characterized by a smooth surface compared to sycamore wood. It retained the characteristics of the surface and the bonding of the fibers while increasing the smoothness of the surface at low temperatures $\left(160-180^{\circ} \mathrm{C}\right)$. Getting affected by the temperature rise gradually began to appear in the roughness of the outer surface, fiber shattering and separation began to show at high temperatures of 200$220^{\circ} \mathrm{C}$. Thus, cedar wood is one of the most heat resistant woods than sycamore wood in terms of the sensitivity of the external surface and fibers at higher temperatures (Fig. $3 \& 4$ ).

Loss in Mass

The wood loses a large part of their mass when exposed to heat and the rate of loss is high at the beginning and then gradually decreases [30]. This is due to the loss of the water content of the wood and thus loses its weight [31]. This depends directly on the chemical composition of the wood, especially on hemicelluloses [32-34]. The percentage of loss in the mass has been calculated as shown in Fig. 5 for sycamore and cedar woods. The results showed that the loss rates in the mass of sycamore wood increased by increasing the 
TABLE 1. Descriptions of sycamore wood specimens after thermal treatment at $\left(160,180,200 \& 220^{\circ} \mathrm{C}\right)$ in $(2,4 \&$ 6 hours).

\begin{tabular}{|c|c|c|c|}
\hline $\begin{array}{l}\text { sycamore wood specil } \\
\text { thermal treatment }\end{array}$ & is before & & \\
\hline Temperatures & 2h & $4 h$ & $6 n$ \\
\hline \multicolumn{4}{|l|}{ Sycamore at $160^{\circ} \mathrm{C}$} \\
\hline Descriptions & Yellow brown colour- & -brown colour & Dark-brown colour- \\
\hline \multicolumn{4}{|l|}{ Sycamore at $180^{\circ} \mathrm{C}$} \\
\hline Descriptions & -brown colour & $\begin{array}{l}\text {-Dark brown colour } \\
\text { Surface roughness- }\end{array}$ & $\begin{array}{l}\text {-Dark brown colour } \\
\text {-Surface roughness }\end{array}$ \\
\hline \multicolumn{4}{|l|}{ Sycamore at $200^{\circ} \mathrm{C}$} \\
\hline Descriptions & Dark brown colour & $\begin{array}{l}\text { Darker-brown colour } \\
\text {-Wider cracks along the } \\
\text { longitudinal grain }\end{array}$ & $\begin{array}{l}\text { Darker-brown colour } \\
\text {-Wider cracks along the } \\
\text { longitudinal grain } \\
\text {-Appearance of cross-grain } \\
\text { fissures }\end{array}$ \\
\hline \multicolumn{4}{|l|}{ Sycamore at $220^{\circ} \mathrm{C}$} \\
\hline Descriptions & $\begin{array}{l}\text { Black colour } \\
\text {-Shrinkage } \\
\text {-Longitudinal cracks } \\
\text {-Some hair-line cross-grain } \\
\text { fissures }\end{array}$ & $\begin{array}{l}\text {-Black colour } \\
\text {-Very well-burnt char } \\
\text { with a lot of cracks and } \\
\text { fissures } \\
\text {-Very fragile (broke } \\
\text { when touched) }\end{array}$ & $\begin{array}{l}\text {-Black colour } \\
\text {-Very well-burnt char with } \\
\text { a lot of cracks and fissures } \\
\text {-Very fragile (broke when } \\
\text { touched) }\end{array}$ \\
\hline
\end{tabular}

temperature from 160 to $180^{\circ} \mathrm{C}$ at a constant rate and by increasing the exposure time, the mass loss rates increased, and this continued to increase with increasing the temperature up to $200^{\circ} \mathrm{C}$. With the continuous increasing in heat exposure time, the mass loss rate gradually declined again, although the increase in heat exposure time continued with rising the temperature up to $220^{\circ} \mathrm{C}$, the rate of loss in the mass increased, but the continuous increase in the heat exposure time led to decrease in the rate of loss in mass once again.

In respect of cedar wood, the rate of loss in mass increased slowly when samples were exposed to temperatures 160 and $180^{\circ} \mathrm{C}$. The 
TABLE 2. Descriptions of Cedar wood specimens after thermal treatment at $\left(160,180,200 \& 220^{\circ} \mathrm{C}\right)$ in $(2,4 \& 6$ hours).

\begin{tabular}{|c|c|c|c|}
\hline \multicolumn{3}{|c|}{$\begin{array}{l}\text { Cedar wood specimens before } \\
\text { themnal treatment }\end{array}$} & \multirow[b]{2}{*}{$6 \mathrm{~h}$} \\
\hline Temperatures & $4 h$ & $2 \mathrm{~h}$ & \\
\hline \multicolumn{4}{|l|}{ Cedar at $160^{*} \mathrm{C}$} \\
\hline Descriptions & -Yellow brown oolour & -Yellow brown colour & -Dark-brown colour \\
\hline \multicolumn{4}{|l|}{ Cedar at $180^{\circ} \mathrm{C}$} \\
\hline Descriptions & -brown colour & Dark-brown colour- & -Dark brown colcur \\
\hline \multicolumn{4}{|l|}{ Cedar at $180^{\circ} \mathrm{C}$} \\
\hline Descriptions & -Dark-brown colour & $\begin{array}{l}\text { Dark brown colour } \\
\text { Surface roughness }\end{array}$ & $\begin{array}{l}\text { Datk brown colour } \\
\text { Surface roughness }\end{array}$ \\
\hline \multicolumn{4}{|l|}{ Cedar at $200^{\circ} \mathrm{C}$} \\
\hline Descriptions & $\begin{array}{l}\text { Black colour } \\
\text {-Longitudinal cracks } \\
\text {-Sorne hair-line cross-grain } \\
\text { fissures }\end{array}$ & $\begin{array}{l}\text {-Black colour } \\
\text {-Shrinkage } \\
\text {-Very well-burnt char with } \\
\text { a lot of cracks and fissures } \\
\text {-Very fragile) }\end{array}$ & $\begin{array}{l}\text {-Black colour } \\
\text { - Very well-bumt char } \\
\text { with a lot of cracks and } \\
\text { fissures } \\
\text { - Very fragile (broke } \\
\text { when touched) }\end{array}$ \\
\hline
\end{tabular}

mass loss increased in the first hours when samples were exposed to temperatures 200 and $220^{\circ} \mathrm{C}$ at a constant rate, and by increasing the heat exposure time from ( 2 to 4 ) hours and then to 6 hours, the rate of loss in the mass decreased. By comparing the mass loss rates for both sycamore and cedar woods, it was found that the mass loss rates for sycamore wood are higher than that of cedar wood.

Density

The thermal degradation over time leads to the loss of percentage of cellulose, the main component of the wood. This results in the occurrence of cross cracks, large and deep voids, and by the continuity of thermal degradation, 


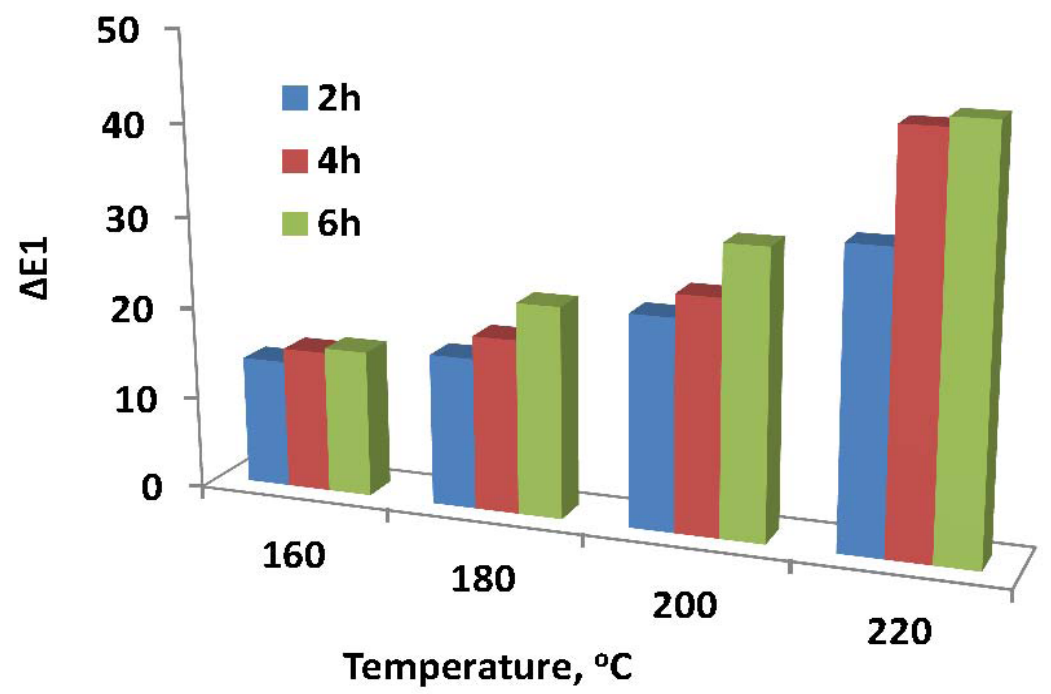

Fig. 1. Color change rates of Sycamore.

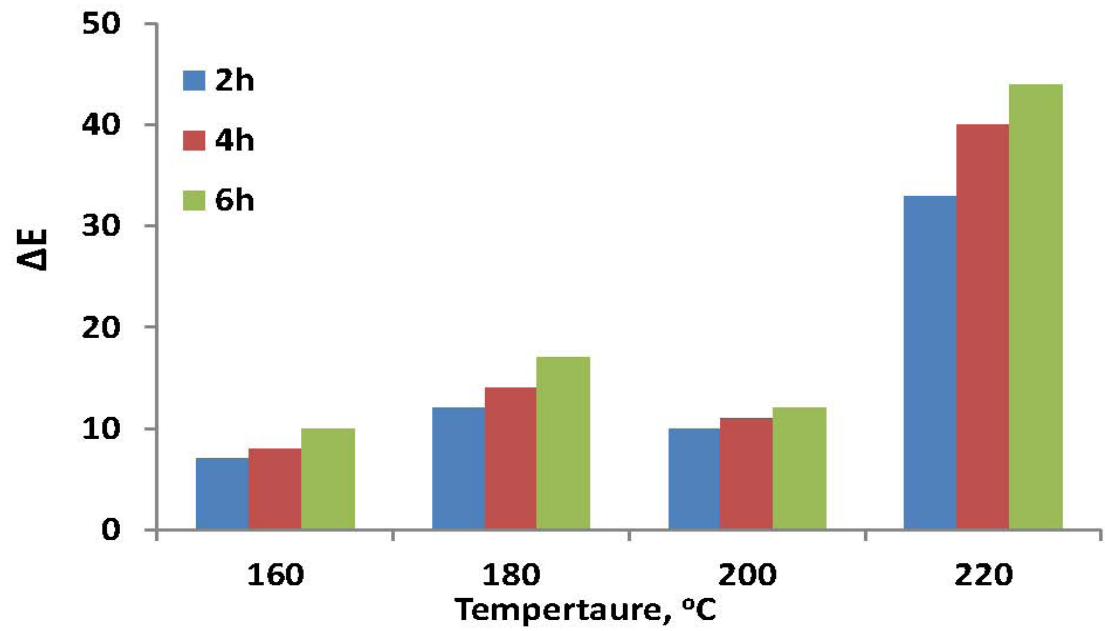

Fig. 2. Color change rates of Cedar wood.

cross cracks increase with the absence of cellulose, the essential asset of wood, which leads to decline of density of wood $[35,36]$. By comparing between the changes in the density rate of reduction of sycamore and cedar woods at the same temperature for the same heat exposure time it shows that. The reduction of density rate of sycamore wood was higher than that of cedar wood as shown in Fig. 6.

\section{Mechanical properties of wood}

Mechanical properties are the properties related to the behavior of wood material when subjected to loads such as pressure and bending [37]. Figures $7 \& 8$ display the bending and compression resistance of both sycamore and cedar wood. By comparing the rate of reduction of the bending and compression resistance between sycamore and cedar woods at the same temperature and for the same heat exposure time, it is apparent that the bending and compression resistance of sycamore wood in the standard sample is higher than the bending and compression resistance in the standard cedar wood sample where that is explained due to the vessels in the hard wood (Sycamore), and the reduction rate of bending and compression 


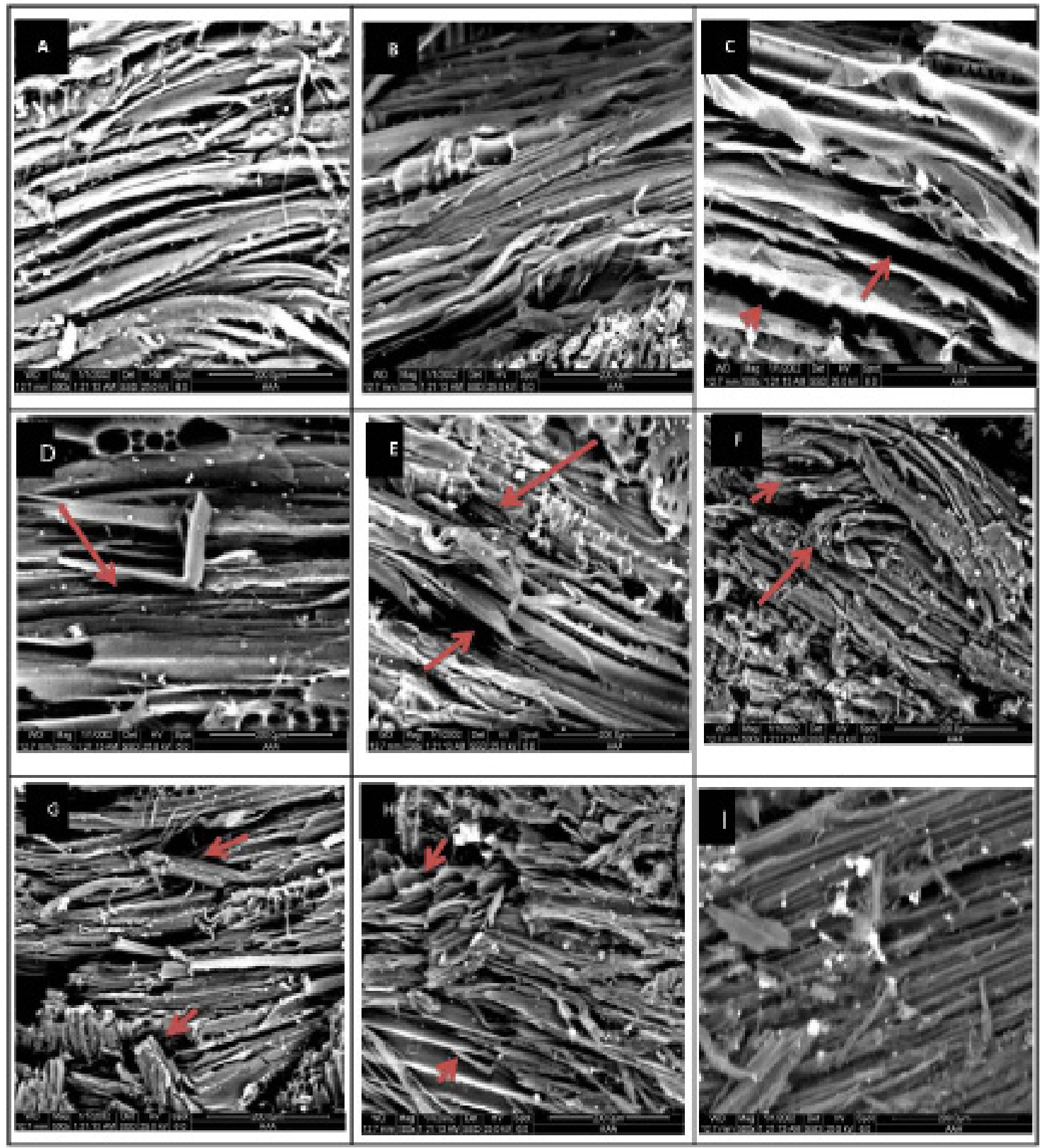

Fig. 3. Sycamore wood sample surface after its exposure to heat treatment.

resistance of sycamore wood after heat treatment was rapid, unlike the cedar wood, which has been regular gradual after heat treatment.

Therefore, the Cedar wood is considered one of the high quality woods, retains its mechanical properties such as (bending resistance and compression resistance) in the high temperature atmosphere circumstances relative to the sycamore wood, which is high mechanically affected by high temperatures due to the presence of water vessels [38].
Anatomical structure of thermally treated wood

The internal deformities resulting from the exposure of the studied samples to heat for different periods of time were examined. Modification of the cell wall structure occurs as a result of the rise in temperature [39] and the emergence of plasticity in the external surface of the samples compared to the standard samples and the cell loss of its strength, accompanied by a breakdown in most of the cell walls after heat treatment. A radial cross section in the sycamore wood and a longitudinal cross section 

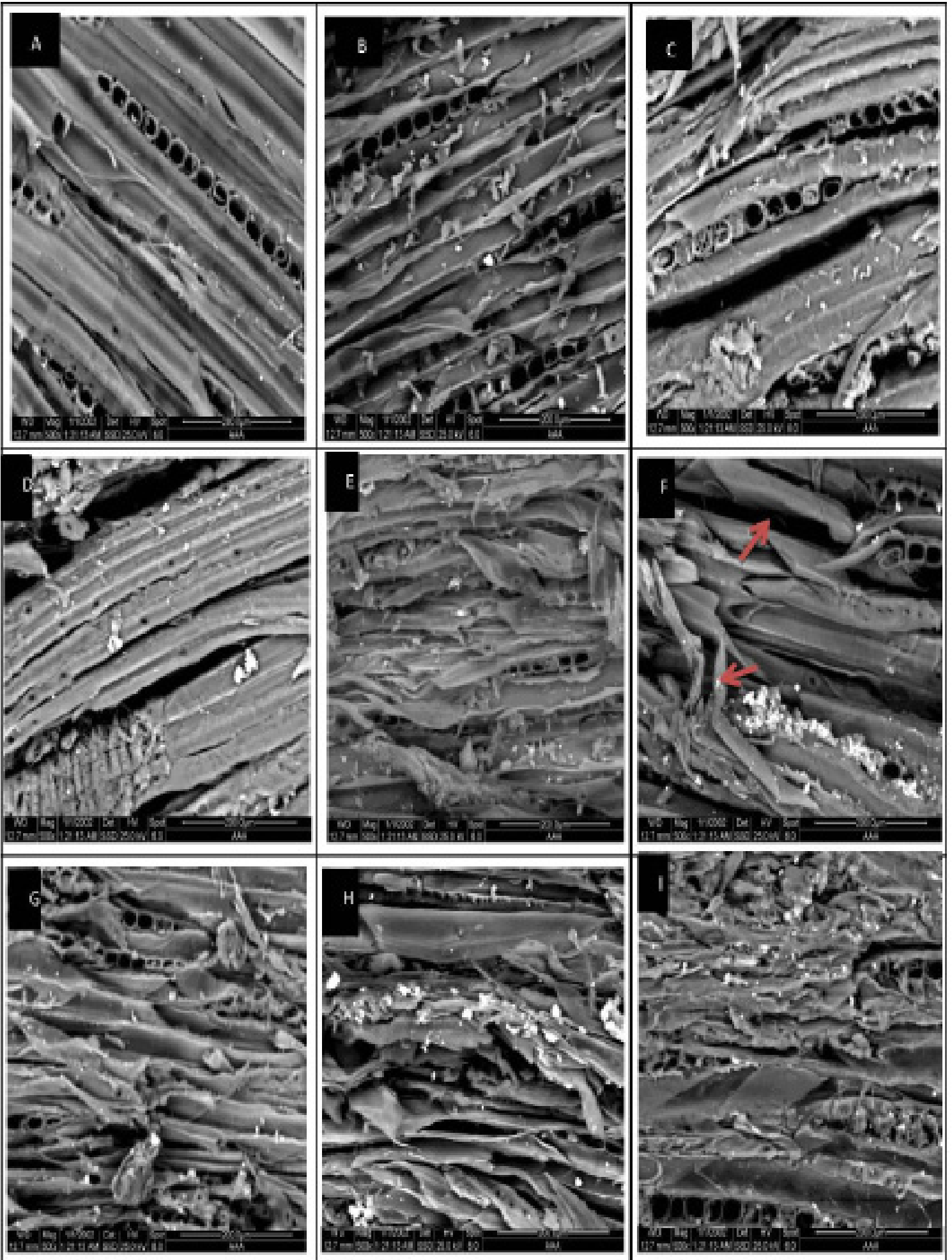

Fig. 4. Cedar wood sample surface after its exposure to heat treatment. 

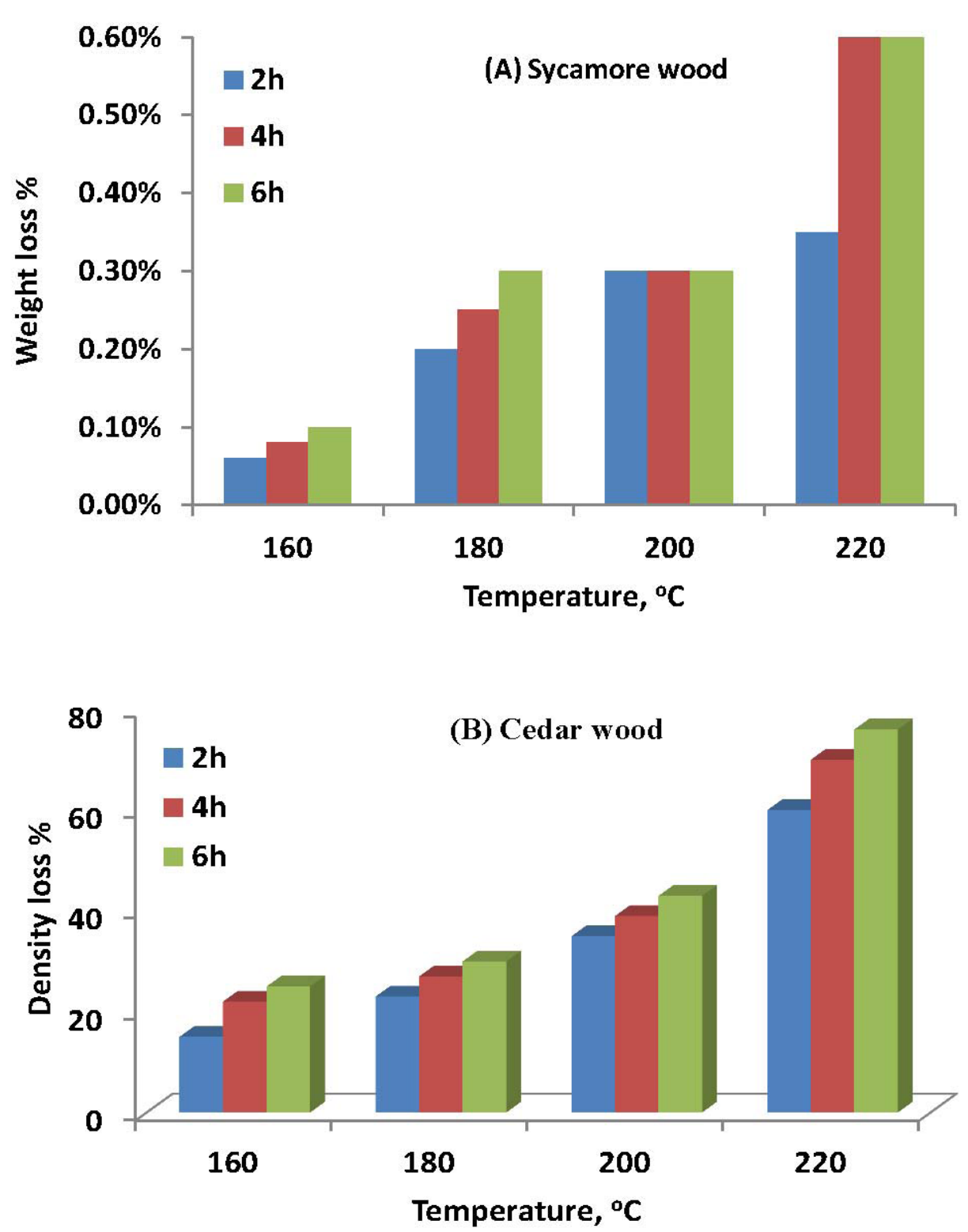

Fig. 5. (A\&B): The rate of weight loss for sycamore and cedar wood.

in the cedar wood, which are the most affected sections by heat. This was evident when bending tests were carried out, where breakage took place in the radial section of sycamore wood and the longitudinal section of cedar wood. The samples were examined at temperatures $(160,180,200 \&$ $220^{\circ} \mathrm{C}$ ) for 2 and 6 hours.

Figures 9 and 10 demonstrated that the internal deformations of the cell walls as a result of the exposure of the samples of both sycamore and cedar woods. Both types of wood were affected by heat beginning from temperature $160^{\circ} \mathrm{C}$, with the increase in the rate of damage by the increase in temperature, till $220^{\circ} \mathrm{C}$. It is may be attributable to the rates of damage to sycamore wood were higher than that of cedar wood at different temperatures, as severe deterioration has occurred to the sycamore wood at different temperatures compared to cedar wood.

\section{Thermal analysis}

Non-isothermal degradation in static air atmosphere, for all wood species, occurs through three successive processes accompanied by mass losses [40]. Figure 11 revealed that the mass losses of the samples of both sycamore and cedar woods. Each wood species shows: (1) an endothermic 

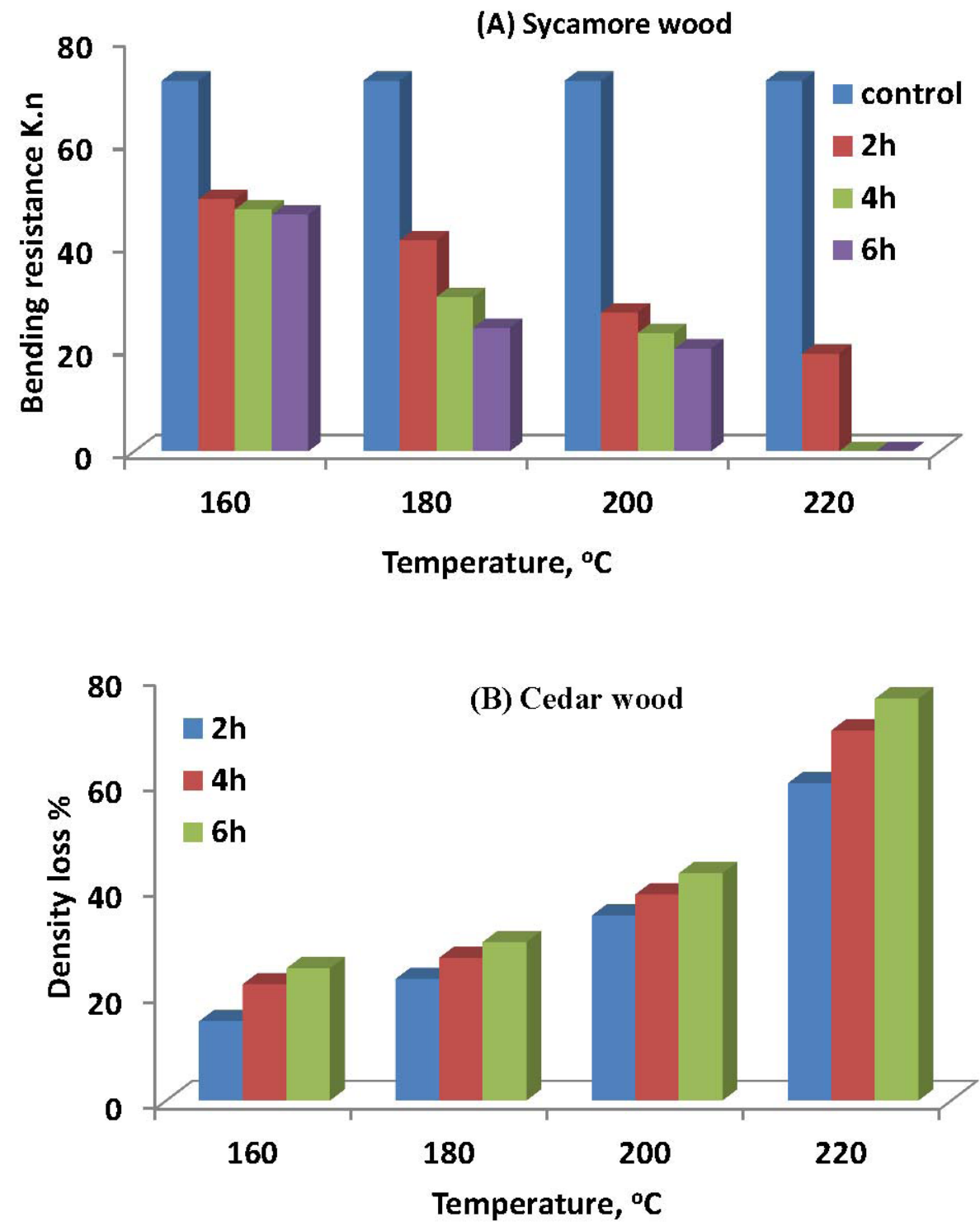

Fig. 6. (A\& B): Rate of density loss for Sycamore and Cedar wood.

process, denoted as, when water loss takes place, (2) an exothermic process, denoted as consisting of thermal degradation assigned to cellulose and hemicelluloses, over the $250-380{ }^{\circ} \mathrm{C}$, (3) an exothermic process, denoted as, assigned to lignin, over the 400-500. By comparing the change in the mass loss ratios of sycamore and cedar woods shows that the mass loss ratios of hemicelluloses and cellulose to lignin of sycamore wood was higher than that of hemicelluloses and cellulose to lignin in cedar wood.
$X$-ray diffraction analysis $(X R D)$

The XRD pattern was used to calculate the degree of crystallization of cellulose in wood samples [41, 42]. The degree of crystallization of thermally treated wood was calculated through the diffraction curve at $\left(160,180,200 \& 220^{\circ} \mathrm{C}\right)$ at two time periods; 2 and 6 hours. Figure 10 exhibited that the low degree of crystallization in both of sycamore and cedar samples with the continuity of heat treatment, with the sycamore wood more affected by the heat treatment, as it showed a rapid decrease in the crystallization 

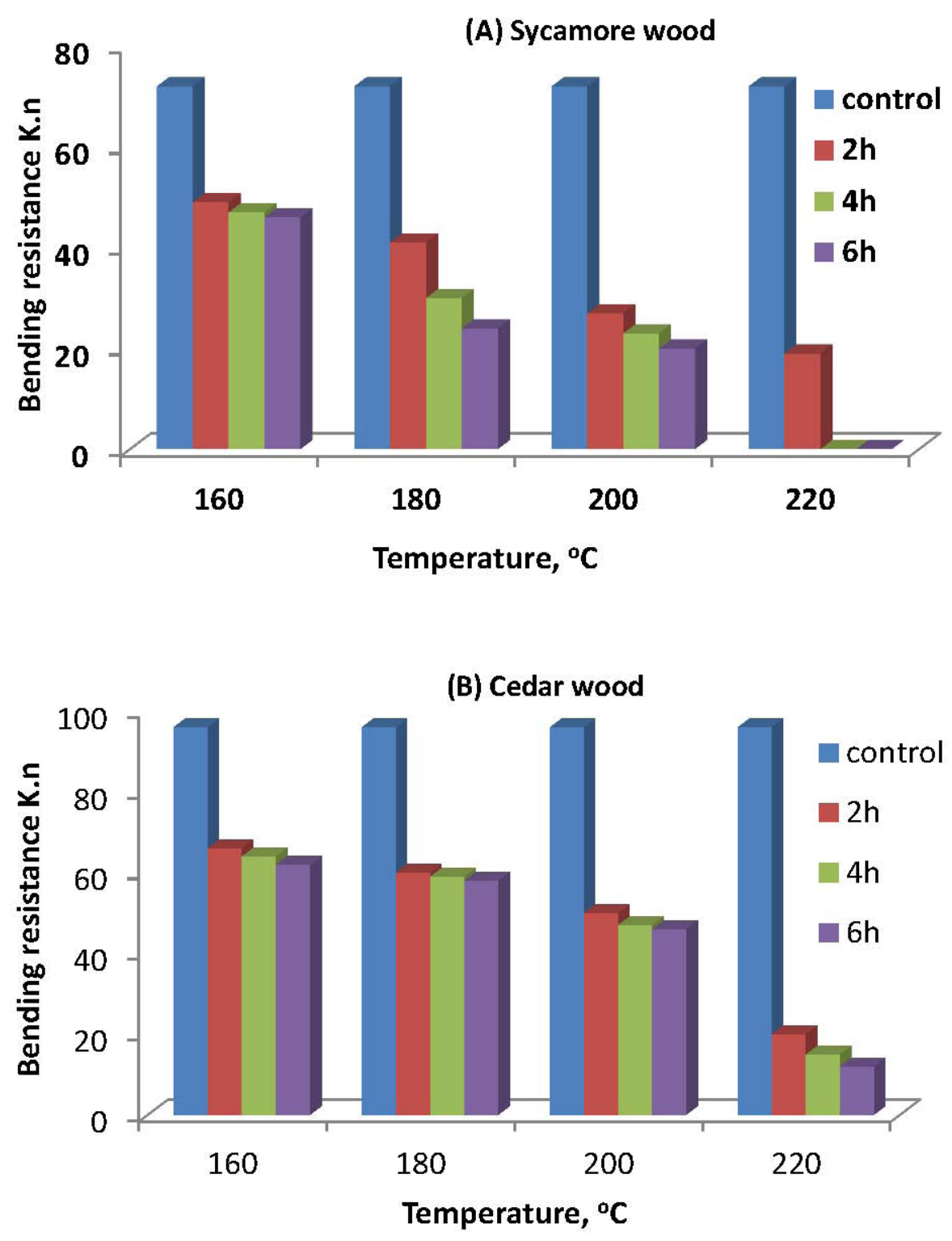

Fig. 7. (A\&B). Bending resistance for Cedar and Sycamore wood

from (63 to $6 \%$ ) as shown in Table 3 , and the cedar wood showed more heat resistance, as its decrease in the crystallization from (56 to $10 \%$ ) after the heat treatment as revealed in Fig. 12.

\section{Infrared analysis (FTIR)}

FTIR is a method of qualitative analysis used to identify functional groups in molecules of organic matter [43-45], by identifying changes in peaks of absorbance [46], Each type of wood has its pattern of infrared rays characteristic thereof, with some common features [47, 48]. When exposed to heat, severe changes occur in absorption areas, which differ from one type of wood to another, confirming chemical changes due to heat treatment [36, 49]. Figure 13 demonstrations spectral analysis of both sycamore and cedar woods at $160,180,200 \& 220^{\circ} \mathrm{C}$ in two time periods of exposure ( $2 \& 6$ hours), where the change in the general structure of cellulose 

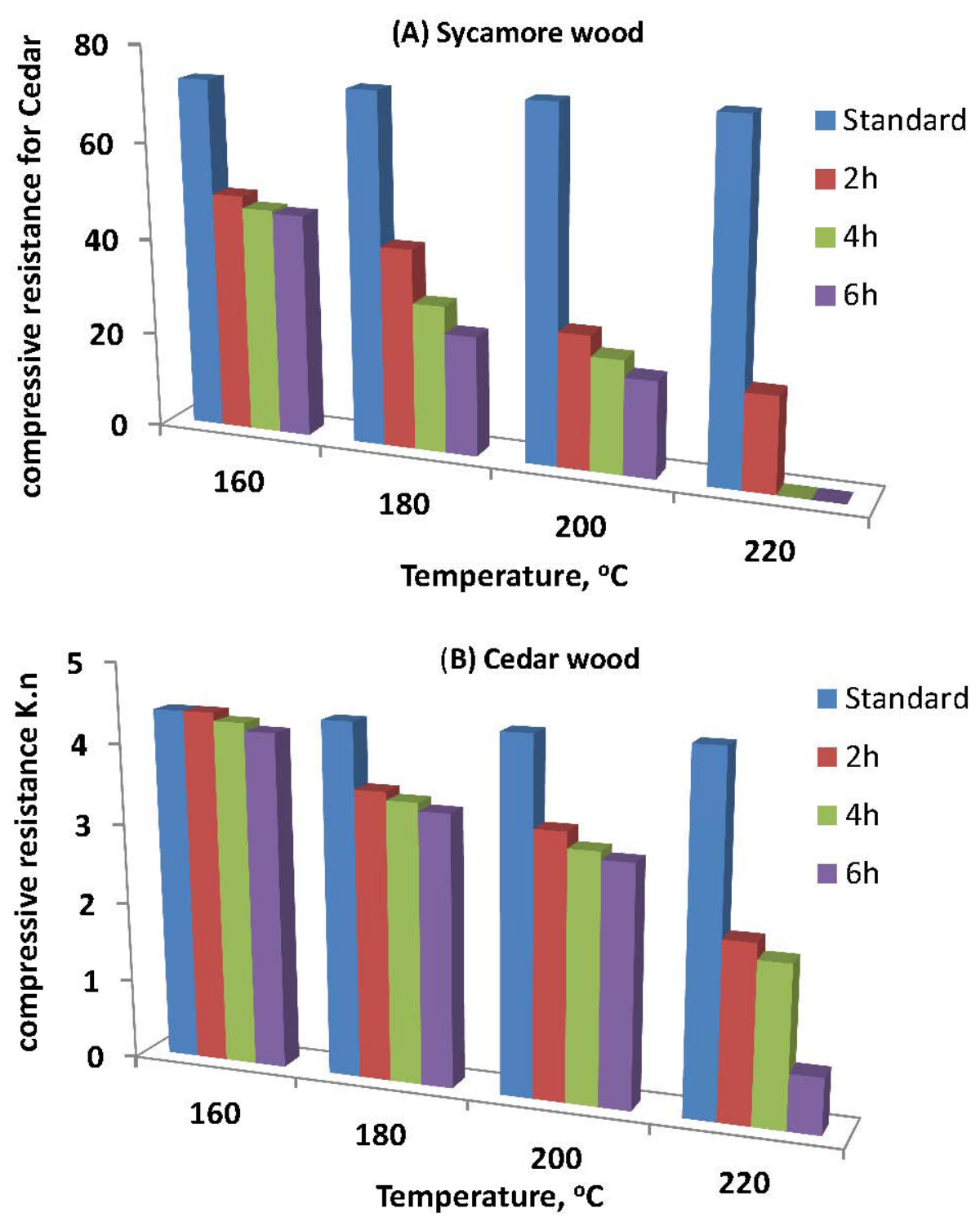

Fig. 8. (A\&B): Compressive resistance for Cedar and Sycamore wood.

through an increase in some of the absorption characteristic of a group of cellulose areas and shortage in other areas and the formation of new groups.

\section{Conclusion}

Cedar wood was found more stable in heat resistance than sycamore wood. By comparing the mass loss rates for both sycamore and cedar woods, it was found that the mass loss rates for sycamore wood are higher than that of cedar wood. After conducting mechanical tests on the wood, the sycamore showed that it is more stable than the cedar wood in the onset of the heat treatment, due to the water vascular in sycamore wood, and with continuous heat treatment, the rates of mechanical characteristics for sycamore wood has declined rapidly, on the contrary to the cedar wood, where it has been more stable than sycamore wood post heat treatment. FTIR and $\mathrm{XRD}$ analyses proved that cedar wood is one of the woods of higher quality than sycamore wood, as it showed higher chemical stability than sycamore wood. 

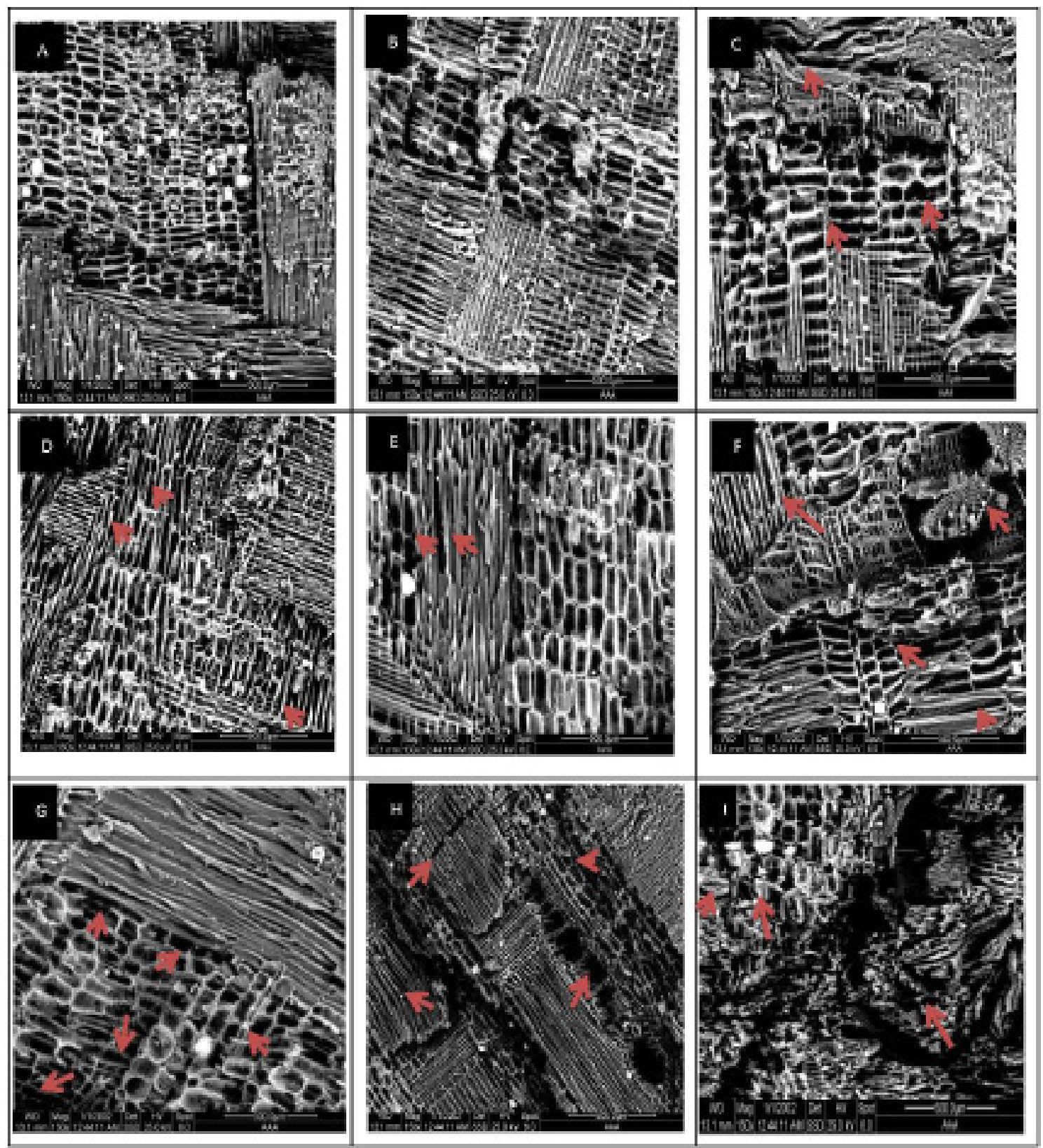

Fig. 9. Radial cross section in a sample of Sycamore wood, after exposure to heat. 

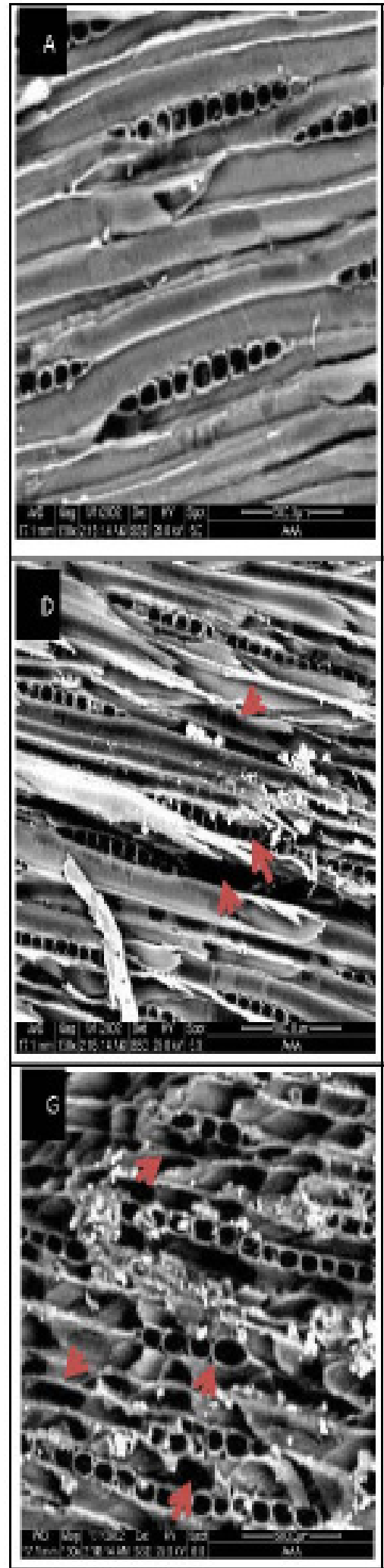
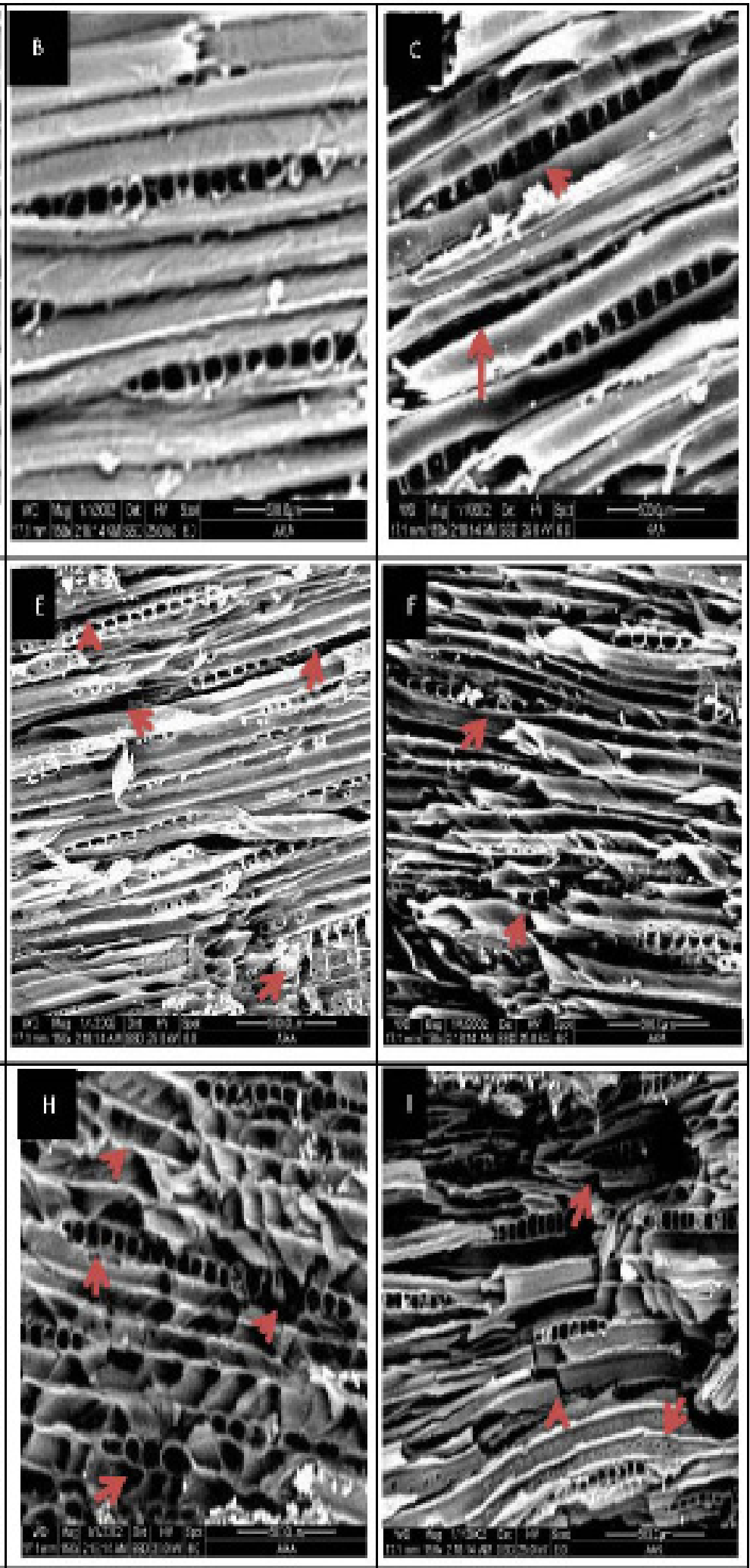

Fig. 10. Longitudinal cross section in a sample of Sycamore wood, after exposure to heat. 


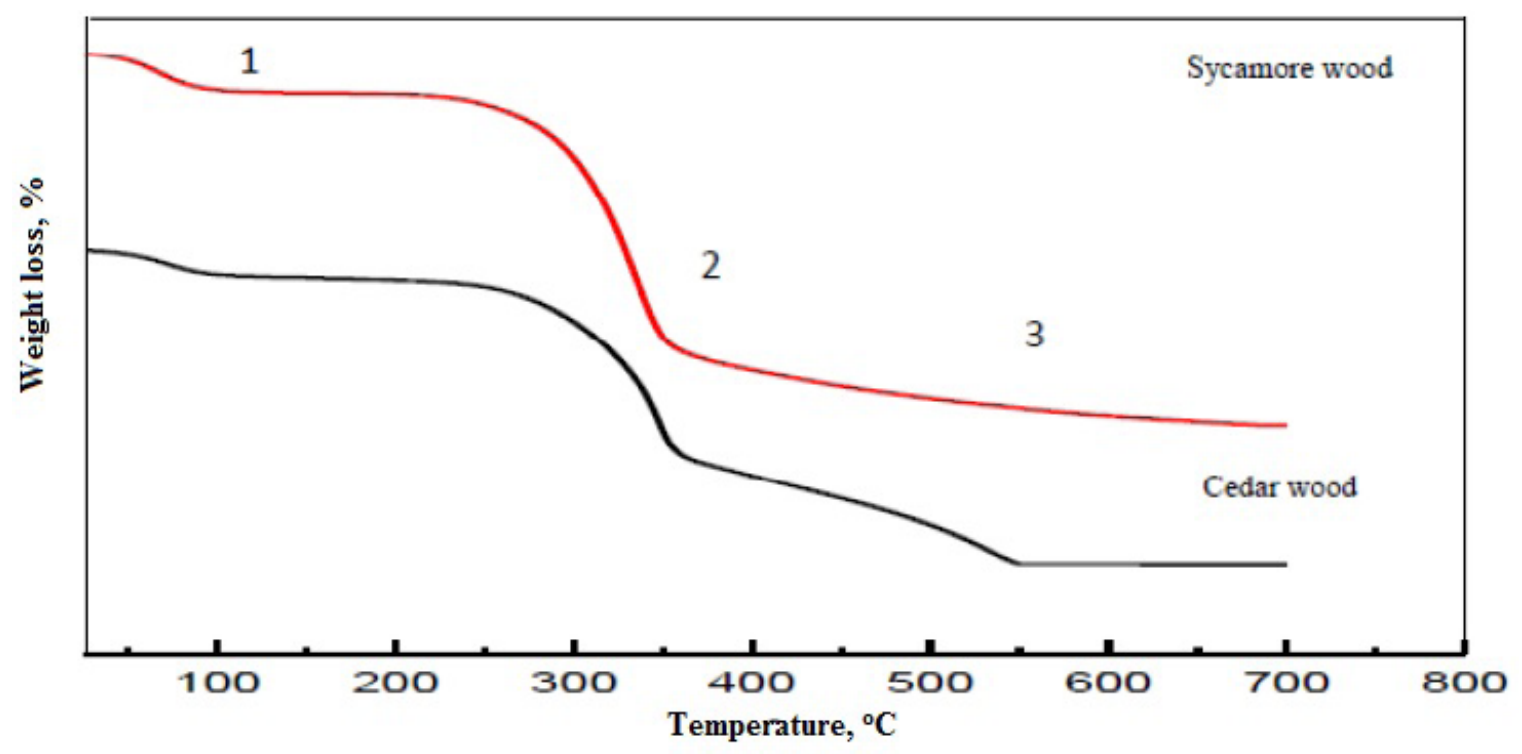

Fig. 11. TGA of Sycamore and Cedar wood
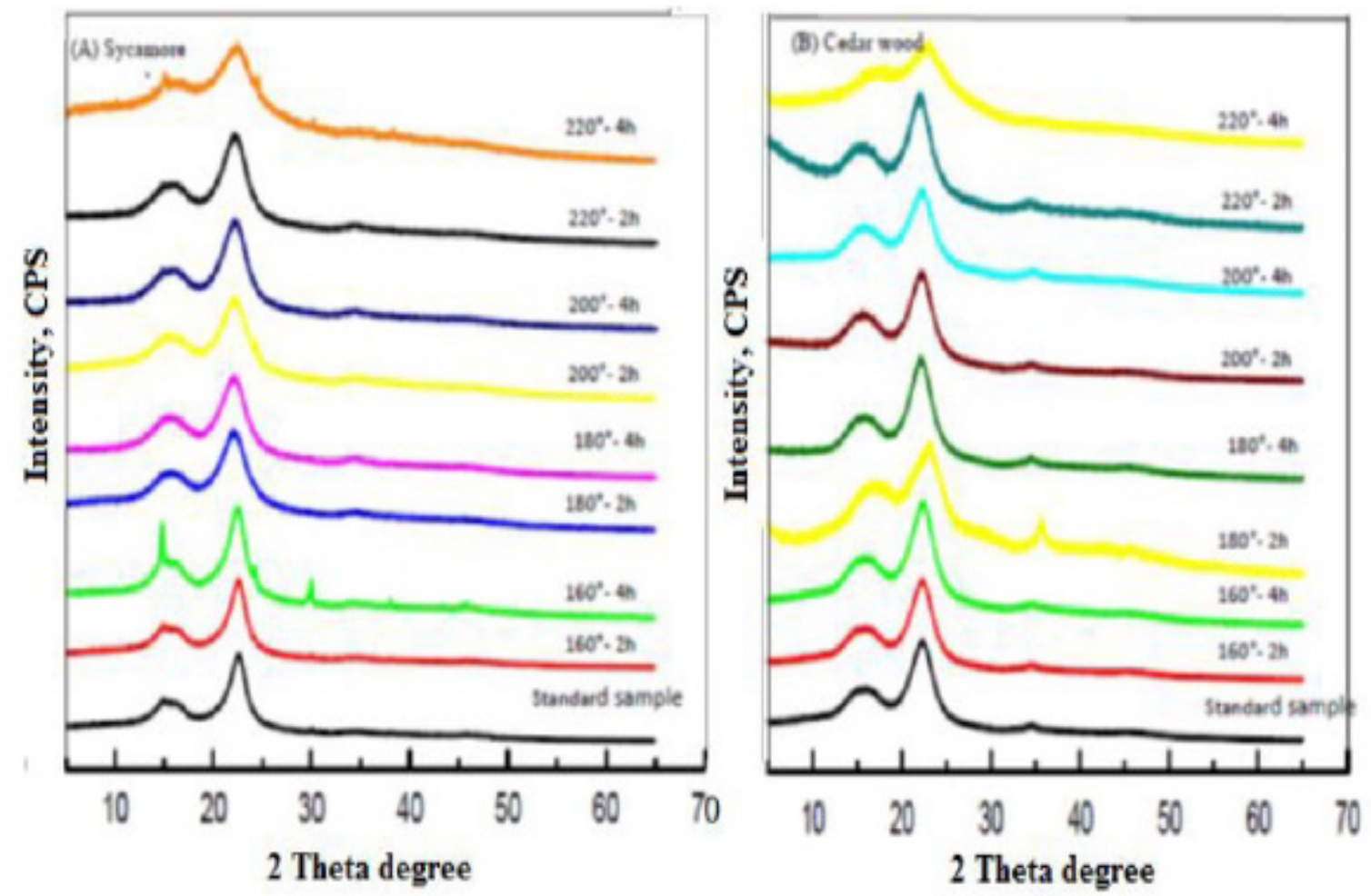

Fig. 12. Cellulose analysis by X-ray deviation of the Sycamore and Cedar wood 
TABLE 3. Degree of crystallization of thermally treated Sycamore and Cedar wood

\begin{tabular}{|c|c|c|c|c|c|c|c|c|}
\hline Temp. $\left({ }^{\circ}\right.$ C) & \multicolumn{2}{|c|}{160} & \multicolumn{2}{c|}{180} & \multicolumn{2}{c|}{200} & \multicolumn{2}{c|}{220} \\
\hline Time (hour) & 2 & 6 & 2 & 6 & 2 & 6 & 2 & 6 \\
\hline Sycamore & 63.0 & 55.9 & 42.0 & 31.0 & 27.0 & 26.0 & 11.0 & 06.0 \\
\hline Cedar & 56.0 & 52.0 & 54.0 & 48.5 & 30.5 & 29.9 & 14.0 & 10.0 \\
\hline
\end{tabular}
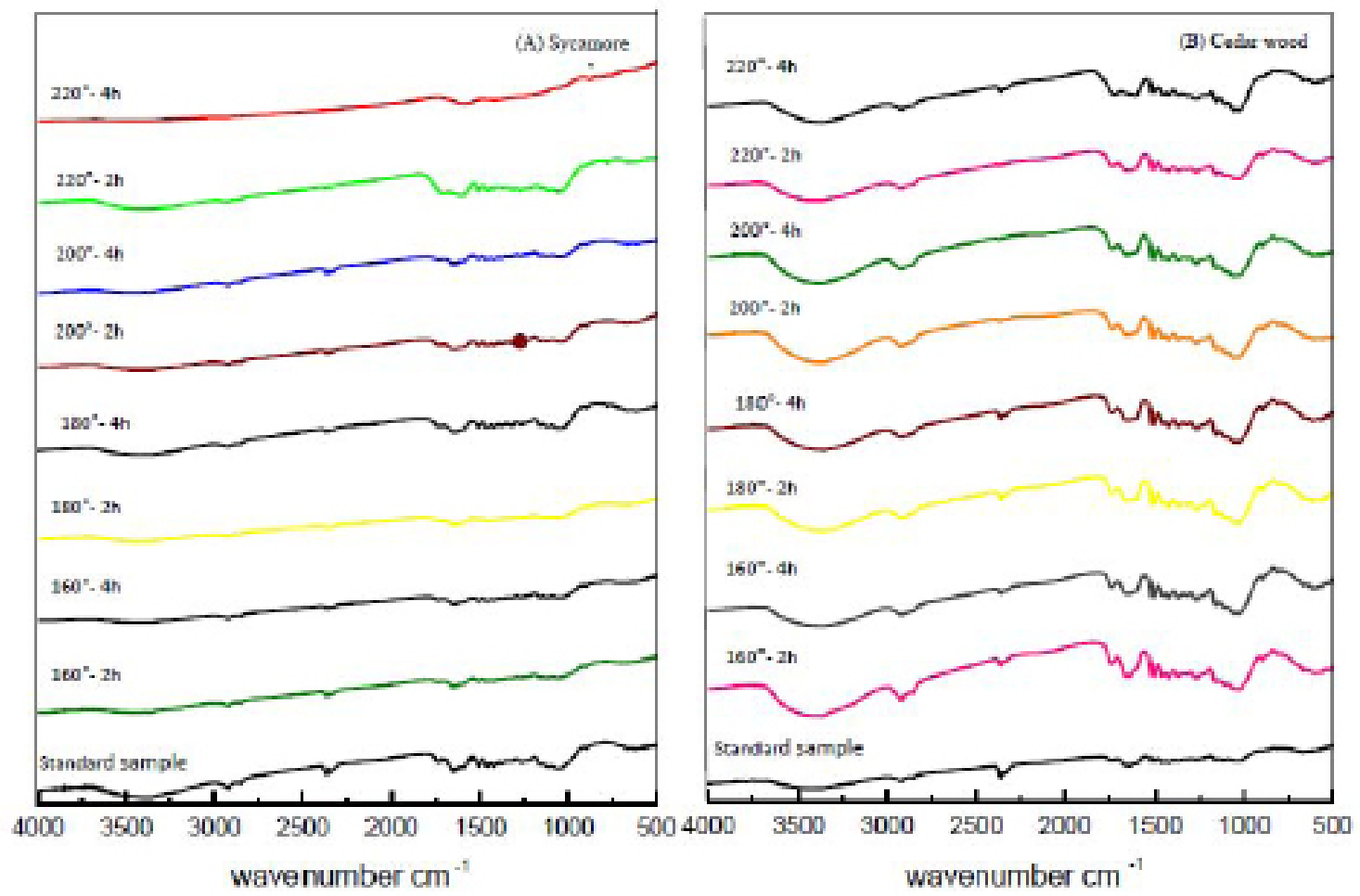

Fig. 13. Change in the general structure of cellulose of Sycamore and Crdar wood

\section{References}

1. Huisman D. J., Degradation of archaeological remains. All figures Cultural Heritage Agency1,56-87 (2009).

2. Winandy J., Wang Q. \& White R., Fire retardant treated strand board: properties and fire performance, Wood Fiber Sci. 40 (1), 62-71(2008).

3. Mohamed O. A., Youssef A. M., El Samahy M. A. and Bloch J.F., Fire retardant cartoon by adding modified leather waste, Egypt. J. Chem, 59 (2), 553-268 (2016).

4. Blanchette R.A., A review of microbial deterioration found in archaeological wood from different environments, International

Egypt. J. Chem. 61, No.6 (2018)
Biodeterioration \& Biodegradation 46, 189-204 (2000).

5. Bjørn P. J, Petra R., \& Per Jostein H., Investigations of Accelerated Climate Aged Wood Substrates by Fourier Trans form Infrared Material Characterization Advances in Materials Science and Engineering, 2012, 1-6 (2012)

6. Kacik F., Šmira P., Kacikova D., Reinprecht L. \& Nasswettrova A., Chemical changes in Fir wood from old buildings due to aging. Cellulose Chemistry and Technology, 48, 79-88 (2014).

7. Liodakis D., Bakirtzis A., Dimitrakopoulos, Autoignition \& thermogravimetric analysis of forest species treated with fire retardants, 
Thermochim. Acta, 399, 31-42 (2003).

8. Youssef A. M., Mohamed S. A., Abdel-Aziz M. S., Abdel-Aziz M. E., Turky G., Kamel S., Biological studies and electrical conductivity of paper sheet based on PANI/PS/Ag-NPs nanocomposite. Carbohydrate Polymers, 147, 333-343 (2016).

9. Huisman J.P., Degradation of archaeological remains. Sdu Uitgevers b.v. Den Haag, 123-143 (2009).

10. Eylem D., Tomak E. \& Huseyin P., The effect of some wood preservatives on the thermal degradation of Scots pine. Thermo chimica Acta 547, journal homepage: www.el sevier.com/ locate/tca (2012).

11. Chew N, Pyrolysis of tropical hardwood under long-term and low temperature conditions, International Journal on Architectural Science, 8, 17-27 (2011).

12. Florian M., Dale P. \& Norton R., The Conservation of Artifacts Made from Plant Materials," U.S.A., 165 (1997).

13. Miyuki M., Misao Y. \& Et, Evaluation of the aging wood from historical buildings as compared with the accelerated aging wood and cellulose-Analysis of color properties- International Conference on Wooden Cultural Heritage, Evaluation of Deterioration and Management of Change, $U$. Noldt (Ed), Hamburg (DE), 7-10 (2013).

14. Monica E., Goran G.\& Gunnar H., Wood Chemistry and Biotechnology, Pulp and Paper Chemistry and Technology Volume 1, publication in the Deutsche National bibliografie; detailed bibliographic data are available in the Internet at http://dnb.d-nb.de (2009).

15. Madison W.I., Wood Handbook-Wood as an Engineering Material, U. S. Department of Agriculture, Forest Service, Forest Products Laboratory. 463 (1999).

16. Gunduz G., Korkut S. \& Korkut D., The effects of heat treatment on physical and technological properties and surface roughness of Camiyani Black Pine (Pinusnigra Arn. subsp pallasiana var. pallasiana) wood. Bioresource Technol, 90, 22752280 (2008).

17. Ozcan S ., Ozcifci A., Hiziroglu S., Toker H., Effects of heat treatment and surface roughness on bonding strength. Constr Build Mater., 33, 7-13 (2012).
18. Hiziroglu S. \& Suzuki S., Evaluation of surface roughness of commercially manufactured particleboard and medium density fiberboard in Japan. J Mater Process Technol., 184, 436-40 (2007).

19. Kocaefe D., Poncsak S., Tang J. \& Bouazara M., Effect of heat treatment on the mechanical properties of North American jack pine: Thermo gravimetric study. J Mater Sci., 45, 681-687 (2010).

20. Barbaros Y., Anatomy of Lebanon Cedar (CEDRUS LIBANI A. RICH.) wood with indented growth rings, Polish Academy of Sciences, Acta Biologicala Cracoviensia Series Botanica 49 (1), 19-23 (2007).

21. El Hadidi N., The Cheops Boat -50 Years Later. Proceedings of the International Conference, Florence 22-27 February, Vol. 1 and 2, (2005).

22. Abdrabou A., Abdallah M., Abd El Kader M., Analytical study and conservation processes of a painted wooden Graeco - Roman Coffin, International Journal of Conservation Science, $\mathbf{6}$ (4), 573-586 (2015).

23. Rushdy A. M., Wahba W. N., Youssef A. M. and Kamel S., Influence of Bleaching Materials on Mechanical and Morphological Properties for Paper Conservation, Egypt. J. Chem., 60 (5), 893 - 903(2017)

24. Blasi C.D., Modeling chemical and physical processes of wood and biomass pyrolysis, Progress in Energy and Combustion Science, 34, 47-90 (2008).

25. Jamsa S. \& Viitaniemi P., Heat treatment of wood better durability without chemicals. In: Rapp AO editor. Review on heat treatments of wood. Cost action E22. Proceedings of Special Seminar, Antibes, France, 17-22 (2001).

26. Bekhta P., Niemz P., Effect of high temperature on the change in color, dimensional stability and mechanical properties of spruce wood, Holzforschung, 57, 539-546 (2003).

27. Pandey K. \& Vuorinen T., UV resonance Raman spectroscopic study of photo degradation of hardwood and softwood lignins by UV laser. Holzforschung 62 (2), 183-188 (2008).

28. Moore A. \& Owen N., Infrared spectroscopic studies of solid wood. Appl Spectrosc Rev., 36, 6586 (2001). 
29. Ergun B. \& Saban K., Some Physical Characteristic of Thermally modified Orient-Beech Wood Madera's. Cienciay Tecnología, 16 (3), 291-298 (2014).

30. Korkut D.S. \& Guller B., The effects of heat treatment on physical properties and surface roughness of red-bud maple (Acer trautvetteri Medw) wood. Bioresource Technol; 99 (8), 28462851(2008).

31. Aydin I. \& Colakoglu G., Effects of surface inactivation, high temperature drying and preservative treatment on surface roughness and colour of alder and beech wood. Applied Surface Science, 252, 430-440 (2005).

32. Inari N. G., Petrissans M. \& Gerardin P., Chemical reactivity of heat treated wood, Wood Science and Technology, 41 (2), 157-168 (2007).

33. Lojewska J., Lubanska A., Lojewski T., Miskowiec P. \& M.Proniewicz L., Kinetic Approach to Degradation of Paper. In situ FTIR Transmission Studies on Hydrolysis and Oxidation, Directory of Open Access Journal, 2, 317, 1-12 (2005).

34. David W., Robert L., Wershaw A. \&. Larry G, Changes in Composition and Porosity Occurring During the Thermal Degradation of Wood and Wood Components, Scientific Investigations Report - 5292 (2004).

35. Bakar B., Hiziroglu S. \& Tahir P., Properties of some thermally modified wood species. Materials and Design, 43, 348- 355 (2013).

36. Lojewska J., Miskowiec P., Lojewski T. \& Proniewicz L., Cellulose oxidative and hydrolytic degradation: in-situ FTIR approach, Polm. Degrad. Stab., 88, 512-520 (2005).

37. Nuopponen M., Thermal Modification of Wood and FT-IR and UV Raman Spectroscopic; Studies of its Extractable Compounds, Ph.D. Thesis, Helsinki University of Technology Laboratory of Forest Products Chemistry, Reports, Series A 23, Espoo, Finland 48-39 (2005).

38. Barry A., Wood Preservation. Published by E \& FN Spon, an imprint of Chapman \& Hall, 2-6 Boundary Row, London SE1 8HN (1993).

39. Baldock J.A. \& Smernik R.J, Chemical composition and bioavailability of thermally altered Pinus resinosa (Red pine) wood, Organic Geochemistry, 33, 1093-1109 (2002).

40. Emandi A., Vasiliu C., Budrugeac P. \& Stamatin
I., Quantitative investigation of wood composition by integrated FT-IR and Thermogravimetric methods, Cellulose Chemistry and Technology, 45 (9-10), 579-584 (2011).

41. Youssef A. M., El-Gendy A., Kamel S., Evaluation of corn husk fibers reinforced recycled low density polyethylene composites. Materials Chemistry and Physics, 152, 26-33 (2015).

42. Yamamoto T., Yoshida H.M, Crystallinity of cellulose micro fibrils in wood cell wall by repeated dry -and-wet treatment using X-ray diffraction technique. Springer Cellulose Journal, No. 20, 633-643(2013).

43. Schwanninger M., Rodrigues J.C., Pereira H. \& Hinterstoisser B., Effects of short-time vibratory ball milling on the shape of FT-IR spectra of wood and cellulose, Vibrational Spectroscopy 36, 2340 , on line at www.sciencedirect. (2004).

44. Petter Jelle B., Ruther R., \& Hovde J., Investigations of Accelerated Climate Aged Wood Substrates by Fourier Transform Infrared Material Characterization, Advances in Materials Science and Engineering, Article ID 827471, 6 pages doi:10.1155/2012/827471(2012).

45. Colom X., Carrillo F., Nogues F. \& Garriga P., Structural analysis of photodegraded wood by means of FTIR spectroscopy, Polymer Degradation and Stability, 80, (3), 543-549 (2003).

46. Mohebby B., Attenuated total reflection infrared spectroscopy of white-rot decayed beech wood, International Biodeterioration and Biodegradation, 55 (4), 247-251(2005).

47. Sudiyani Y., Imamura Y., Doi S. \& Yamauchi S., Infrared spectroscopic investigations of weathering effects on the surface of tropical wood, Journal of Wood Science, 49 (1), (2003).

48. Kocaefe D., Huang X., Kocaefe Y. \& Boluk Y., Study on Weathering Behavior of Jack Pine Heat-Treated under Different Conditions. Journal of Energy and Power Engineering, 7, 818-826 (2013).

49. Nuopponen M., Wikberg H., Vuorinen T., Maunu S.L., Jämsä S., Viitaniemi P., Heat-treated softwood exposed to weathering, Journal of Applied Polymer Science, 91, 2128-2134 (2004).

(Received 4/7/2018; accepted 2/8/2018)

Egypt. J. Chem. 61, No.6 (2018) 
تقيّيم الخواص الفيزيائية والميكانيكية والكيميائية لخثب الارز والجميز بعد المعالجة

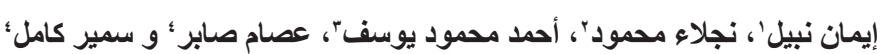
' متحف خوفو - مصر. كانقم التزميم- كلية الآثار - جامعة الفيوم - مصر.

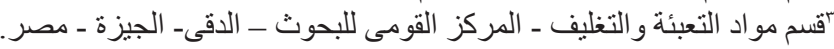

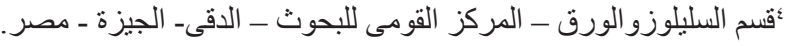

يهرف هذا البحث إلى دراسة تأثير الحرارة على نوعين من الخشب (الأرز - الجميز) فى محاولة لمحاكات تأثير

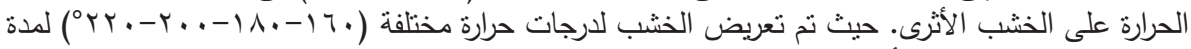

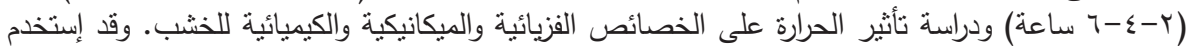

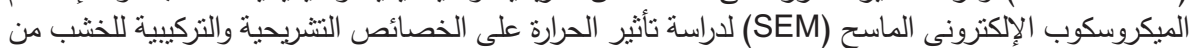

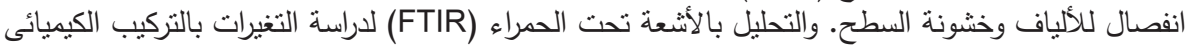

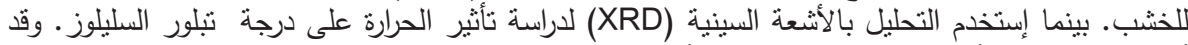

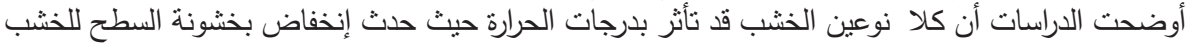

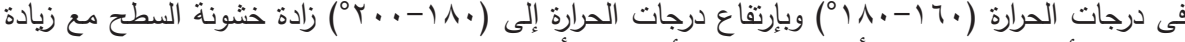
انفصال الألياف. وبشكل عام أظهرت عينات الأرز جودة أعلى فى مقاومة الحرارة عن خشب الجميز . 